\title{
Role of Foreign Direct Investment in Multi-Brand Retailing Sector in India
}

\author{
${ }^{1}$ Venkatanarayana Miriyam, ${ }^{2}$ Hanumanthappa.S \\ ${ }^{1,2}$ Assistant Professor in Commerce, Government Degree College, Sindhanur -584128.
}

\begin{abstract}
Necessity always necessitates searching for the alternatives"
In developing countries like India, because of low per capita income there would be always scarcity of capital. As a consequence, underutilization of natural resources, unemployment and underemployment, low productivity \& technological undergrowth, shortage of skilled labour, economical imbalance and unhealthy balance of payments become more prominent.

Countries continuously in need of investment for their development especially in emerging countries like India. To be frank, the source of investment may be obtained through public or private funding, but the total finance required would generally be above the capital which may be available within the country's boundaries. Foreign Direct Investment (FDI), therefore, becomes an important financial source for capital projects which would be vital for development of emerging countries.

As a matter of fact, the intensity of flow of finance in the form of FDI would generally depend upon the policies and regulations framed by Government to attract Foreign Direct investment (FDI). The Retail Industry is the paramount sector of economy which comprises individuals, stores, commercial complexes, agencies, companies, and organizations, etc., involved in the business of merchandizing diverse finished products to the end-users directly and indirectly. Products or services of the retail sector are the finished final products or services of all sectors of commerce and play an important role in economy of a country. The Retail sector of India is gigantic and has huge prospective for growth and development as the majority of its elements are unorganized.
\end{abstract}

Empirical study has shown that some emerging countries exposed to Foreign Direct investment (FDI) have a higher socio-economic growth rate than those that have not exposed to it. Thus, FDI becomes a vital energized tool for growth of economy for India.

\section{Introduction:}

Capital flows in form of Foreign Direct investment (FDI) has been key in the intensive development of countries for centuries, from 1492 with the "discovery" of America and even before. The colonization of territories by more developed nations has been possible due to Foreign Direct investment (FDI). Moreover, the concept of Globalization has enforced the interdependence of countries and clear acceleration of their economic growth in the past three decades.

Underdeveloped countries, especially those classified as emerging countries have been enthusiastic in attracting investment to enrich their development in vital sectors. As an alternative way for source of required finance to enrich the economic development, governments started making changes in their policies to make their countries more attractive to the foreign investor.

For the first time in India, a large Foreign Direct investment (FDI) was attracted after implementation of new economic policy in capital market sector during 1991. On $15^{\text {th }}$ September 2012, Indian government, after several rounds of debates and discussions held with the experts, has announced economic reforms pertaining to multi-brand-retailing sectors that will have healthy effect on economy over a long-run. The Government has allowed up to 51\% of Foreign Direct investment (FDI) in Multi-brand Retail and 100\% in single brand retail to attract the enthusiastic international Multi brand Retailers to setup shops in India.

This paper indents throw a beam of light on the advantages of Foreign Direct investment (FDI) in Multi-Brand retail sector.

\section{Meaning and definitions of FDI:}

Generally speaking, Foreign Direct investment (FDI) refers to the investment made by the foreign investor. FDI refers to investment in a foreign country where the investor retains control over the investment. It typically takes the form of starting a subsidiary, acquiring a stake in an existing firm or starting a joint venture in the foreign country.

Strictly speaking, "FDI refers to the investment that is made to acquire a lasting interest in an enterprise operating in an economy other than that of the investor. The investor's purpose is being to have an effective voice in the management of the enterprise." 
According to the International Monetary Fund "Direct investment reflects the aim of obtaining a lasting invest by a resident entity of one economy (Direct investor) in an enterprise that is resident in another economy (The Direct investment Enterprise). The "lasting invest" implies the existence of a long-term relationship between the direct investor and the direct investment enterprise and a significant degree of influence on the management of the Later".

\section{Need for FDI}

- It is necessary for the Economic Growth of the country.

- It is needed to import necessary technology from the developed countries.

- It brings other scarce productive factors like- technical know-how, business experience and knowledge, which are equally essential for economic development.

- It presents a short-run solution for the balance of payment crisis.

- It develops basic economic infrastructure.

- Foreign investment results in a pattern of growth which is desirable from the point of view of underdeveloped countries

- FDI bridges the gap between savings and investments which accelerate the economic development.

\section{Foreign Direct investment (FDI) in India:}

Starting from a base line of less than $\$ 1$ billion in 1990, a recent United Nations conference on Trade and Development (UNCTAD) survey projected India as the second most important Foreign Direct investment (FDI) destination (after China) for transnational corporations during 2010-12.As per the data, the sectors which attracted higher inflows were services, telecommunication, construction activities and computer and hardware. Mauritius, Singapore, U.S. and UK were among the leading sources of Foreign Direct investment (FDI).According to Ernst and Young, Foreign Direct investment (FDI) in India in 2010 was \$44.8 Billion, and in 2011 experienced an increase of $13 \%$ to $\$ 50.8$ billion. India has seen an Eightfold increase in its Foreign Direct investment (FDI) in March 2012.

India disallowed overseas corporate bodies (OCB's) to invest in India. But on $14^{\text {th }}$ September 2012, governament of India allowed Foreign Direct investment (FDI): in aviation up to 49\%, in Broadcast sector up to $74 \%$, in Multi-Brand retail up to $51 \%$ and in single-brand retail up to $100 \%$.

\section{Advantages of FDI in Multi-Brand Retailing:}

Retailing is one of the worlds largest private Industry. Liberalizations in Foreign Direct investment (FDI) have caused a massive restructuring in retail industry. The benefit of Foreign Direct investment (FDI) in retail industry superimposes its cost factors. Opening the retail industry to Foreign Direct investment (FDI) will bring forth benefits in terms of advance employment, organized retail stores, availability of quality products at a better and cheaper price. It enables a country to expose its product or service to the global market.

\section{Cheaper Production \& Distribution Facilities:}

Foreign Direct investment (FDI) ensures better operations in production cycle and distribution. Due to economies of operation, production facilities will be available at a cheaper rate thereby resulting in availability of variety products to the ultimate consumers at a reasonable and lesser price.

\section{Availability of Advanced Technology:}

Foreign Direct investment (FDI) enables transfer of skills and technology from overseas and develops the infrastructure of the domestic country. Greater managerial talent inflow from other countries is made possible. Domestic consumers will benefit getting great variety and quality products at all price points.

\section{Long-Term Healthy Cash Liquidity:}

Foreign Direct investment (FDI) will provide necessary capital for setting up organized retail chain stores. It is a long term investment because unlike equity capital, the physical capital invested in the domestic company is not easily liquidated.

\section{Lead Driver For The Economic Growth Of The Country:}

Foreign Direct investment (FDI) would create a competition among the global investors, which would ultimately ensure better and lower prices thus benefiting people in all sections of the society. There would be an increase in the market growth and expansion. It will increase retail employment and suffers untrained manpower and lack of experience. It will ensure better managerial techniques and success. Higher wages will be paid by the international companies. Urban consumers will be exposed to international lifestyles. 


\section{FDI Opens New And Safe Way For Franchising:}

Restrictions on Foreign Direct investment (FDI) are considered as trade barriers as they deny direct market access to foreign firms. Retail giants who are at their own wings, seeking entry into foreign market would look for other available alternatives. These restrictions on the global retailers regarding the inflow of Foreign Direct investment (FDI), leads them towards acquiring the market entry through franchises. Thus, countries which offer promising market potentialities for retail growth offers substantial growth in the franchising sector as well.

\section{Success Story of Foreign Direct Investment (FDI) In China}

China is the world's largest Foreign Direct investment (FDI) recipient, and has used it deftly to increase its exports. It started with a Foreign Direct investment (FDI) investment of $\$ 19$ billion in 1990, and reached $\$ 300$ billion in 1999.40 retailers now have a secured approval in the Chinese market. Foreign Direct investment (FDI) has created an encouraging effect in both traditional as well as modern formats of retail business in China.

\begin{tabular}{|l|r|r|}
\hline Stores & 1996 & 2001 \\
\hline Traditional & 1920604 & 2565028 \\
\hline Supermarkets & 13079 & 152194 \\
\hline Convenience & -- & 18091 \\
\hline hypermarkets & -- & 593 \\
\hline
\end{tabular}

Carrefour from France, Tesco from England, Metro from Germany, and Wall-Mart from US have entered the Chinese retail sector and has uplifted the country's economy. Initially during 1992, China allowed Foreign Direct investment (FDI) only in a few selected cities and also restricted the ownership by $26 \%$. China continues to hit new records. More than 28 Million people and approximately $10 \%$ of Chinas total population are working in companies funded with Foreign Direct investment (FDI).

\section{Conclusion:}

"Every event should be weighed in the light of merits and demerits; if the event proves more relative benefits then it should be accepted as positive practice"

With the advent of Foreign Direct investment (FDI), retail sector is likely to make massive strides and catalyze the economic growth of the country. Indeed, it is the life blood of economy for developing nations. 